Artikel Penelitian

\title{
Aktivitas Larvasida Fraksi N-Heksan Ekstrak Etanol Daun Mengkudu (Morinda citrifolia. L) terhadap Larva Aedes sp.
}

\section{Larvicide Activity of N-Hexane Fraction of Ethanolic Morinda citrifolia. L Leaves Extract on Aedes sp. Larvae}

\author{
Rizki Awaluddin ${ }^{1 *}$, Binti Sholihatin ${ }^{1}$, Nurul Marfu'ah ${ }^{1}$, Kurniawan $^{1}$, Solikah Ana Estikomah ${ }^{1,2}$ \\ ${ }^{1}$ Program Studi Farmasi, Universitas Darussalam Gontor, Jawa Timur 63261, Indonesia \\ ${ }^{2}$ Program Doktor Ilmu Lingkungan, Universitas Sebelas Maret, Jawa Tengah 57126
}

Kutipan: Awaluddin R, Solihatin B, Marfu'ah N, Kurniawan NM, Estikomah SA. Aktivitas Larvasida Fraksi N-Heksan Ekstrak Etanol Daun Mengkudu (Morinda citrifolia .L) terhadap Larva Aedes sp.. ASP. Desember 2021: 13(2): 137-146

Editor: Yuneu Yuliasih

Diterima: 25 April 2021

Revisi: 13 September 2021

Layak Terbit: 17 November 2021

Catatan Penerbit: Aspirator tetap netral dalam hal klaim yurisdiksi di peta yang diterbitkan dan afiliasi kelembagaan.

\section{(c) 0}

Hak Cipta: (C) 2021 oleh penulis. Pemegang lisensi Loka Litbangkes Pangandaran, Indonesia. Artikel ini adalah artikel dengan akses terbuka yang didistribusikan dengan syarat dan ketentuan lisensi Creative Commons Attribution Share-Alike (CC BY SA) (https://creativecommons.org/ licenses/by-sa/2.0/)

*Korespondensi Penulis Email: rizkiawaluddin@unida.gontor. ac.id
Abstract. Aedes sp. is a vector of the dengue virus that causes Dengue Hemorrhagic Fever (DHF). Larvicides are the optimal method for controlling mosquito development. Temephos is a larvicidal agent of the organophosphate group which is reported to cause side effects and ecological hazards, as well as resistance based on reports in several country. This study aims to determine the larvicidal activity of the n-hexane fraction of Morinda citrifolia leaf ethanol extract on Aedes sp. The compound groups in the fraction were identified using TLC through UV light and spray reagents. There were six types of treatment including four concentration fractions $(400,600,800$, and $1000 \mathrm{ppm})$ as treatment, positive control (temephos 1\%) and negative control 1\% acetone solution. Twenty-five mosquito larvae of Aedes sp. tested for each treatment. Larval mortality was recorded and $L C_{50}$ and $L C_{99}$ values were analyzed using the probit. The results showed that the TLC test of the n-hexane fraction was positive for terpenoids, anthraquinones, phenols, tannins, and flavonoids. The results showed that the $L_{50}$ and $L C_{99}$ values were $1040 \mathrm{ppm}$ and $2439 \mathrm{ppm}$. Therefore, the $n$-hexane fraction of the ethanol extract had larvicidal activity on Aedes sp. with little toxicity.

Keywords: Morinda citrifolia, larvicide, Aedes aegypti, n-hexane fraction, DHF

Abstrak. Aedes sp. merupakan vektor virus dengue penyebab Demam Berdarah Dengue (DBD). Larvisida merupakan metode yang optimal untuk mengendalikan perkembangan nyamuk. Temephos yang merupakan larvasida sintetik dapat menyebabkan resisten, efek samping dan bahaya ekologi. Kelimpahan agen hayati, efek toksik pada manusia yang minim, dan biodegradable menjadi tujuan utama perlunya pengembangan agen larvasida baru. Penelitian ini bertujuan untuk mengetahui aktivitas larvasida fraksi n-heksana ekstrak etanol daun mengkudu pada larva Aedes sp. Golongan senyawa pada fraksi diidentifikasi menggunakan KLT melalui pereaksi semprot. Terdapat enam jenis perlakuan diantaranya empat konsentrasi fraksi (400, 600, 800, dan 1000 ppm) sebagai perlakuan, kontrol positif (temephos 1\%) dan kontrol negatif larutan aseton 1\%. Dua puluh lima larva nyamuk Aedes sp. diujikan pada setiap perlakuan. Kematian larva dicatat dan nilai $\mathrm{LC}_{50}$ dan $\mathrm{LC}_{99}$ dianalisa menggunakan probit. Hasil penelitian menunjukkan bahwa uji KLT fraksi n-heksana positif mengandung terpenoid, antrakuinon, fenol, tanin, dan flavonoid. Hasil penelitian menunjukkan bahwa nilai $\mathrm{LC}_{50}$ dan $\mathrm{LC}_{99}$ adalah 1040 ppm dan 2439 ppm. Oleh karena itu, fraksi n-heksana dari ekstrak etanol memiliki aktivitas larvasida pada Aedes sp.

Kata Kunci: Morinda citrifolia, larvasida, Aedes sp., fraksi n-heksana, DBD 


\section{PENDAHULUAN}

Nyamuk Aedes sp. merupakan salah satu vektor yang menularkan penyakit atau dikenal dengan vector-borne disease. ${ }^{1,2}$ Nyamuk Aedes sp. merupakan vektor penyakit Demam Berdarah Dengue (DBD) yang menularkan virus dengue. ${ }^{3}$ Kasus DBD di Indonesia pernah menjadi kejadian luar biasa (KLB) yaitu 21.092 kasus tahun 2015 menjadi 25.336 kasus tahun 2016. Provinsi Jawa Timur kasus DBD mencapai 9.425 pada tahun 2018. ${ }^{4}$ Laporan kasus DBD berkurang setiap tahun, pada tahun 2020 kasus DBD di Jawa Timur 5.948 kasus. ${ }^{5}$ Perkembangan nyamuk dipengaruhi oleh banyak faktor diantaranya kepadatan populasi manusia dan lingkungan yang lembab. Area yang terdapat genangan air seperti sungai, sawah dan rawa merupakan tempat yang tepat untuk perkembangbiakan nyamuk. Selain itu, kepadatan manusia sebagai sumber makanan merupakan daya tarik nyamuk untuk bertahan hidup, maka agen yang dapat membunuh larva nyamuk (larvasida) menjadi kunci untuk menghambat perkembangan larva menjadi nyamuk dewasa. ${ }^{6,7}$

Temephos dan deltamethrin merupakan larvasida yang menjadi program pemerintah dalam mengendalikan nyamuk Aedes sp., namun beberapa negara seperti di Indonesia telah dilaporkan terkait rendahnya sensitifitas larva dan nyamuk Aedes aegypti terhadap permethrin malathion dan deltamethrin. ${ }^{8,9}$ Larvasida sintetis seperti permethrin, malathion dan senyawa organofosfat menunjukkan toksisitas yang kuat terhadap larva nyamuk disamping itu juga dilaporkan adanya efek samping atau toksisitas pada organisme non-target dan bahaya kimia terhadap kelestarian ekologis lingkungan hidup bahkan kesehatan manusia. ${ }^{10}$ Oleh karena itu, perlu dikembangkan larvasida baru yang lebih potensial. Keuntungan pengembangan obat menggunakan bahan alam ialah umumnya etnomedisin lebih aman, senyawa alam sebagai prototype, dan senyawa bahan alam selalu melimpah. Larvasida hayati lebih mudah untuk didegradasi oleh lingkungan (biodegradable) sehingga meminimalkan pencemaran lingkungan. ${ }^{11}$

Daun mengkudu (Morinda citrifolia) mengandung senyawa yang berperan sebagai bioinsektisida yakni flavonoid, alkaloid, saponin dan asam oktanoat yang bersifat larvasida terhadap larva nyamuk. ${ }^{12}$ Pada penelitian sebelumnya, fraksi n-heksan tanaman Ajuga chamaecostus tomentella memiliki aktivitas larvasida pada nyamuk Anopheles stephensi paling tinggi dibanding fraksi kloroform, etil asetat dan metanol yakni dengan nilai $\mathrm{LC}_{50}$ sebesar 95,66 ppm. ${ }^{13}$ Pada fraksi n-heksan Ajuga chamaecistus tomentella ditemukan senyawa Ajugalide- $E$ dan 22-acetylcyasterone yang merupakan senyawa golongan phytosteroid dan triterpene, senyawa golongan tersebut juga ditemukan pada fraksi n-heksan Morinda citrifolia yang dilaporkan mengandung urosolic acid. Kandungan senyawa tersebutlah yang berperan penting dalam aktivitas larvasida. ${ }^{14}$ Tingkat aktivitas dari larvasida dapat ditentukan dengan melihat nilai $\mathrm{LC}_{50}{ }^{15}$ Penelitian terkait aktivitas larvasida daun dan biji Morinda citrifolia pada Aedes sp. sudah pernah dilakukan, akan tetapi bukti ilmiah terkait aktivitas larvasida fraksi n-heksan ekstrak etanol daun Morinda citrifolia pada Aedes sp. masih terbatas. Oleh karena itu penelitian ini dilakukan untuk mengkaji kandungan golongan senyawa pada fraksi n-heksan dan aktivitasnya terhadap larva nyamuk Aedes aegypti.

\section{BAHAN DAN METODE}

\section{Persetujuan Etik Penelitian}

Desain dan prosedur penelitian telah mendapatkan ijin dari Komite Etik Penelitian Kesehatan Universitas Muhammadiyah Surakarta (UMS) dengan nomor EC No.3391.2021. 


\section{Rancangan Penelitian}

Penelitian ini merupakan penelitian eksperimental laboratorium untuk uji mortalitas larva Aedes sp. menggunakan 4 perlakuan dari fraksi n-heksan ekstrak etanol daun mengkudu, 2 kontrol dan 3 ulangan. ${ }^{16}$ Uji larvasida dilakukan dengan desain Post Test Only Control Group Design. Temephos 1\% digunakan sebagai kontrol positif, aseton $1 \%$ sebagai kontrol negatif merujuk pada pedoman uji larvasida oleh WHO. ${ }^{16}$ Fraksi n-heksan ekstrak etanol daun mengkudu digunakan sebagai perlakuan. Media air tanah digunakan sebagai media pertumbuhan yang digunakan dalam penelitian. Telur nyamuk didapatkan di lingkungan Pondok Modern Darussalam Gontor Putri 2 (PMDG-2) menggunakan ovitrap.

\section{Simplisia, Ekstraksi dan Fraksinasi Daun Mengkudu}

Simplisia daun mengkudu di determinasi dan diperoleh dari UPT Materia Medica, Batu, Malang. Daun mengkudu yang digunakan dalam penelitian adalah keseluruhan daun kecuali daun yang menguning atau rusak. Ekstraksi daun mengkudu dilakukan dengan teknik maserasi menggunakan pelarut etanol $96 \%$ berdasarkan penelitian sebelumnya. ${ }^{17}$ Sebanyak $1 \mathrm{~kg}$ simplisia halus daun mengkudu direndam menggunakan 3 liter etanol 96\% dalam gelas beker selama 3 hari, dengan ketentuan diaduk setiap 24 jam sekali. Kemudian disaring dan diuapkan menggunakan vacum rotary evaporator pada suhu $78^{\circ} \mathrm{C}$ hingga diperoleh ekstrak kental. Fraksinasi dilakukan dengan sedikit modifikasi metode pada penelitian yang dilakukan oleh Charisma dkk, 2018 melalui metode fraksinasi cair-cair menggunakan pelarut n-heksana. ${ }^{14}$ Sebanyak 10 gram ekstrak etanol daun mengkudu dilarutkan dengan $75 \mathrm{ml}$ aquades yang telah dididihkan. Kemudian dimasukkan ke dalam corong pisah dan ditambahkan $75 \mathrm{ml}$ n-heksan. Lalu dihomogenkan dan didiamkan hingga terbentuk dua lapisan fraksi air dan fraksi n-heksan. Lapisan atas merupakan fraksi n-heksan, fraksi diambil dan diuapkan menggunakan Vacuum Rotary Evaporator dengan suhu $69^{\circ} \mathrm{C}$. Persen hasil ekstrak dan fraksi dihitung dengan menghitung persentase rendemen hasil ekstraksi atau fraksinasi terhadap berat awal.

\section{Skrining Fitokimia}

Skrining fitokimia dilakukan menggunakan Kromatografi Lapis Tipis (KLT) silica gel GF 254. Senyawa yang akan diidentifikasi adalah golongan terpenoid, antrakuinon, fenol, flavonoid, dan tanin. Identifikasi senyawa golongan terpenoid dan flavonoid dilakukan dengan elusi plat KLT dengan fase gerak n-heksan dan etil asetat (3:2 v/v). Penyemprotan pereaksi Liebermann Burchard digunakan untuk identifikasi terpenoids, sedangkan pereaksi $\mathrm{NaOH}$ 10\% digunakan untuk identifikasi flavonoid. ${ }^{18,19}$

Identifikasi senyawa golongan antrakuinon dan fenolik dilakukan dengan elusi plat KLT dengan fase gerak n-heksan:etil asetat (3:7 v/v), identifikasi senyawa antrakuinon menggunakan larutan $\mathrm{KOH} \mathrm{10 \%} \mathrm{dalam} \mathrm{metanol,} \mathrm{sedangkan} \mathrm{pereaksi}$ $\mathrm{FeCl}_{3}$ digunakan untuk mengidentifikasi senyawa yang mengandung gugus fenolik. ${ }^{18,20}$ Senyawa golongan tanin diidentifikasi menggunakan KLT dengan fase gerak metanol: $\operatorname{air}(6: 4 \mathrm{v} / \mathrm{v})$ dan dideteksi menggunakan pereaksi $\mathrm{FeCl}_{3 .}{ }^{20}$

\section{Telur dan Larva Nyamuk Aedes sp.}

Sampel telur dikumpulkan dari area asrama Universitas Darussalam Gontor Putri Mantingan, Ngawi, Jawa Timur. Pengumpulan telur dilakukan dengan cara memasang perangkap telur (ovitrap). Ovitrap dibuat dari ember berwarna hitam dengan diameter $15 \mathrm{~cm}$. Pada saat pemasangan, ovitrap diisi sepertiganya dengan air dan kertas saring diletakan di sekeliling dinding permukaan dalam ember untuk tempat melekatnya telur nyamuk. Ovitrap diletakkan pada 15 titik area yang diduga tempat berkembangbiak nyamuk, seperti kamar mandi, garasi mobil, belakang asrama, parkiran sepeda, aula 
pertemuan, kebun tanaman, sekitar gedung perkuliahan dan sekitar tempat wudhu/ cuci tangan. Ovitrap dibiarkan dalam kondisi terbuka selama 7 hari dan di identifikasi di bawah mikroskop. Telur yang terperangkap pada kertas saring kemudian dihitung dan larva yang di dapatkan diidentifikasi morfologinya untuk mengetahui jenis nyamuk yang berkembangbiak. Telur disimpan pada suhu $25-28^{\circ} \mathrm{C}$ dengan intensitas cahaya 12 jam terang dan 12 jam gelap hingga menjadi larva instar III. ${ }^{16}$

\section{Uji Aktivitas Larvasida}

Sebanyak 25 larva instar III dimasukkan ke dalam gelas beker $500 \mathrm{ml}$ yang berisi $249 \mathrm{ml}$ air deklorinasi dan $1 \mathrm{ml}$ larutan uji. Selama perlakuan larva diberi makanan. Terdapat 4 perlakuan (Fraksi n-Heksan Ekstrak Etanol Daun Mengkudu dengan konsentrasi 400 ppm, 600 ppm, 800 ppm dan 1000 ppm), kontrol positif, dan kontrol negatif. Setiap uji dilakukan ulangan sebanyak 3 kali. Kontrol negatif dibuat dengan mencampur $1 \mathrm{ml}$ aseton 1\% dengan $249 \mathrm{ml}$ air deklorinasi. Kontrol positif dibuat dengan mencampur $249 \mathrm{ml}$ air deklorinasi dengan $1 \mathrm{ml}$ larutan abate 1\%. Pengamatan kematian larva dilakukan pada 48 jam setelah diberi perlakuan. ${ }^{16}$ Persentase mortalitas dihitung dengan persamaan berikut:

$$
\% \text { mortalitas }=\frac{\text { Mortalitas larva }}{\text { Jumlah larva }} \times 100
$$

\section{Analisis Data}

Data yang didapatkan berupa mortalitas larva pada setiap kelompok uji dianalisis menggunakan program Statistical Product and Service Solution (SPSS) for Windows Release 24.0. Data dianalisis menggunakan regresi probit untuk mengetahui nilai $\mathrm{LC}_{50}$ dan $\mathrm{LC}_{99}$.

\section{HASIL}

Hasil ekstraksi menggunakan pelarut etanol 96\% didapatkan ekstrak kental berwarna hijau gelap sebanyak 61 gram (7.62\%), sedangkan fraksi n-heksan sebanyak $175 \mathrm{mg}$ (2.87\%). Fraksi n-heksan ekstrak etanol yang didapatkan kemudian di identifikasi golongan senyawa menggunakan berbagai pereaksi warna seperti yang ditunjukkan pada Tabel 1 .

Sebanyak 520 larva dan 717 telur didapatkan dari ovitrap yang ditempatkan pada apotek hidup dan garasi rumah (titik perkembangbiakan nyamuk terbanyak). Identifikasi jenis larva yang dilakukan sampling secara acak pada 520 larva didapatkan larva tersebut memiliki ciri-ciri morfologi seperti larva Aedes aegypti (Gambar 1), yakni telur menempel pada kertas saring, bukan mengambang diatas air dan sudut istirahat larva $90^{\circ}$, bentuk siphon yang mengerucut dan pendek, saddle dengan sepasang rambut. ${ }^{21}$

Berdasarkan hasil identifikasi pada fraksi n-heksan ekstrak etanol daun mengkudu menunjukkan bahwa terdapat senyawa yang bereaksi positif terhadap golongan terpenoid, antrakuinon, fenol, tanin, dan flavonoid (Tabel 1.). Warna temuan setelah terjadi dengan adanya senyawa berinteraksi dengan zat pereaksi yang bersifat destruktif.

Tabel 1. Hasil Skrining Fitokimia Fraksi N-Heksan Ekstrak Etanol Daun Mengkudu Menggunakan Pereaksi Warna

\begin{tabular}{lllc}
\hline Golongan Senyawa & \multicolumn{1}{c}{ Pereaksi } & \multicolumn{1}{c}{ Warna Temuan } & Hasil \\
\hline Terpenoid & Lieberman burchard & Kuning, hijau, biru violet & + \\
Antrakuinon & $\mathrm{KOH} \mathrm{10 \%}$ & Merah, hijau, kuning & + \\
Fenol & $\mathrm{FeCl}_{3}$ & $\begin{array}{l}\text { Kuning tua, hijau kehitaman, biru } \\
\text { kehitaman }\end{array}$ & + \\
Tanin & $\mathrm{FeCl}_{3}$ & Hitam & + \\
Flavonoid & $\mathrm{NaOH} 10 \%^{2}$ & Merah kecoklatan, hijau, kuning & + \\
\hline
\end{tabular}




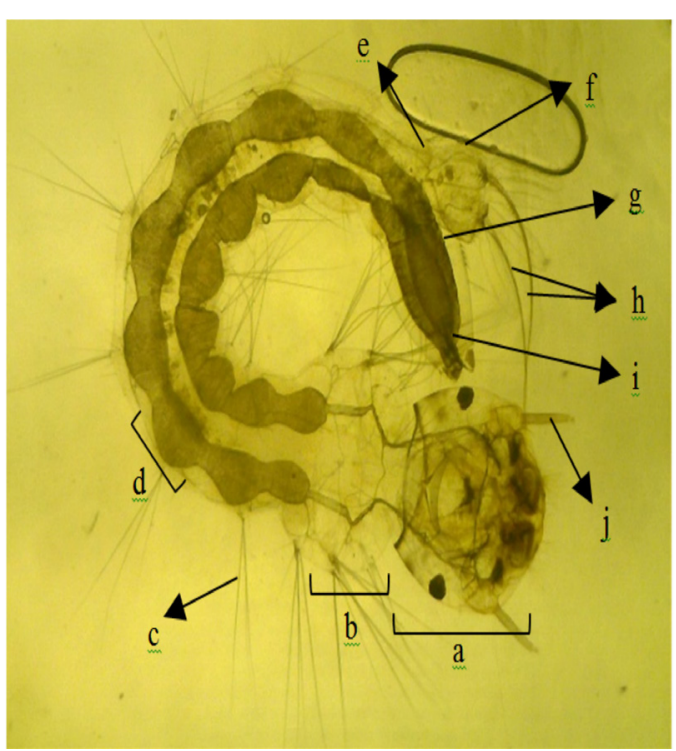

Gambar 1. Morfologi larva Aedes sp. Instar III pada kondisi normal. Nampak jelas rambut pada setiap segmen, siphon berwarna coklat kehitaman, terdapat delapan segmen pada perut, terdapat pekten pada siphon, saddle, comb, dan sepasang anal gill pada ujung saddle. Keterangan: (a) Kepala; (b) Toraks; (c) Rambut; (d) Abdomen/segmen; (e) Comb; (f) Saddle; (g) Pecten; (h) Rambut kaudal; (i) Siphon; (j) Antena.

Uji larvasida dilakukan untuk mengkaji konsentrasi fraksi n-heksan ekstrak etanol daun mengkudu yang dapat membunuh larva nyamuk Aedes sp. Kematian larva ditandai dengan larva yang tidak bergerak dengan posisi terapung atau tenggelam di dasar larutan uji.

Berdasarkan hasil uji larvasida (Tabel 2) menunjukkan bahwa fraksi n-heksan ekstrak etanol daun mengkudu menunjukkan hubungan antara konsentrasi terhadap persentase mortalitas larva (concentration dependent). Namun, persentase mortalitas fraksi n-heksan ekstrak etanol daun mengkudu lebih rendah dibandingkan dengan kontrol positif (Abate 1\%). Nilai $\mathrm{LC}_{50}$ dan $\mathrm{LC}_{99}$ didapatkan dari analisis probit, dan didapatkan nilai $\mathrm{LC}_{50}$ dan $\mathrm{LC}_{99}$ berturut-turut, yaitu 1040 ppm dan 2439 ppm.

Tabel 2. Aktivitas Larvasida Fraksi n-Heksan Ekstrak Etanol Daun Mengkudu (Morinda citrifolia) pada Larva Nyamuk Aedes sp.

\begin{tabular}{|c|c|c|c|c|c|c|}
\hline \multirow{2}{*}{ Perlakuan (ppm) } & \multicolumn{3}{|c|}{ Mortalitas larva nyamuk (\%) } & \multirow{2}{*}{$\begin{array}{c}\text { Rata-Rata \% } \\
\text { Mortalitas } \pm \text { SD }\end{array}$} & \multirow{2}{*}{$\mathbf{L C}_{50}$} & \multirow{2}{*}{$\mathrm{LC}_{99}$} \\
\hline & Replikasi-1 & Replikasi-2 & Replikasi-3 & & & \\
\hline Fraksi 400 ppm & 12 & 16 & 16 & $14.67 \pm 2.31$ & \multirow{4}{*}{1040 ppm } & \multirow{4}{*}{2439 ppm } \\
\hline Fraksi 600 ppm & 24 & 20 & 24 & $22.67 \pm 2.31$ & & \\
\hline Fraksi 800 ppm & 32 & 32 & 36 & $33.33 \pm 2.31$ & & \\
\hline Fraksi 1000 ppm & 52 & 44 & 48 & $48.00 \pm 4.00$ & & \\
\hline Aseton 1\% (K-) & 4 & 0 & 0 & $1.33 \pm 2.31$ & - & - \\
\hline Temephos 1\% (K+) & 100 & 100 & 100 & $100.00 \pm 0.00$ & - & - \\
\hline
\end{tabular}

\section{PEMBAHASAN}

Aedes sp. berbeda dengan Culex sp. dan Anopheles sp. dalam menentukan tempat peletakan telur dan karakteristik telur nyamuk. Aedes sp. memiliki kebiasaan meletakkan telur pada air jernih dalam kontainer. Telur yang mengapung di permukaan air akan menempel pada dinding kontainer seiring waktu akibat adanya gaya adhesi dan penuruan permukaan air akibat penguapan. Kertas saring pada dinding ovitrap berfungsi sebagai perangkap telur pada kontainer tersebut. Telur Aedes sp. memiliki lapisan kutikula (chitin) yang lebih tebal dari kedua nyamuk lainnya. Ketebalan chitin 
tersebut akan memengaruhi kemampuan bertahan telur terhadap dehidrasi. ${ }^{22-24}$ Pada hasil pemasangan ovitrap menunjukkan bahwa telur nyamuk menempel pada kertas saring secara tersebar. Hal ini berbeda dengan nyamuk Anopheles dan Culex yang meletakkan telur di atas permukaan air.22 Penelitian ini menggunakan larva Aedes sp. Instar III. Fase instar merupakan fase perkembangan larva, yakni masa pematangan genetik dan organ. Fase instar III merupakan fase yang tepat untuk uji larvasida karena lapisan kutikula (chitin) akan menebal pada instar IV sedangkan fase instar I dan II rentan mati. Lapisan kutikula memengaruhi penetrasi zat kedalam tubuh larva melalui kulit, sehingga pada larva instar IV agen larvasida akan sulit menembus lapisan kutikula. ${ }^{22}$ Berdasarkan ciri-cirinya, morfologi instar 3 yaitu berukuran $4-5 \mathrm{~mm}$, rambut mulai terlihat jelas, siphon berwarna coklat kehitaman, terdapat delapan segmen pada perut, terdapat pekten pada siphon, terdapat saddle, terdapat comb, dan terdapat anal gill pada ujung saddle. Pada larva instar 4 memiliki ciri yang khas yakni nampak lapisan kitin yang telah menebal dan berwarna gelap. ${ }^{25,26}$ Adapun ciri khas yang membedakan larva aedes dengan larva nyamuk spesies yang lain pada penelitian ini adalah terbentuk sudut $90^{\circ}$ saat larva pada kondisi istirahat dibawah permukaan air, bentuk siphon yang mengerucut dan pendek serta saddle dengan adanya sepasang rambut.

Pada Farmakope Herbal Indonesia menyebutkan bahwa senyawa skopoletin merupakan senyawa penanda (fingerprint compounds) pada Morinda citrifolia yang merupakan senyawa golongan kumarin dengan gugus fenolik. ${ }^{27}$ Berdasarkan hasil uji fitokimia, Fraksi n-heksan mengandung senyawa dengan gugus fenolik yang ditandai dengan perubahan warna pada bercak KLT menjadi lebih gelap (kuning tua. hijau kehitaman dan biru kehitaman. Perbedaan perubahan warna disebabkan oleh perbedaan golongan senyawa.

Mekanisme aksi dan senyawa yang berperan penting sebagai larvasida pada fraksi n-heksan ekstrak etanol daun mengkudu belum diketahui secara jelas. Namun peneliti sebelumnya menjelaskan secara umum mekanisme aksi golongan senyawa terhadap kematian larva. Pada penelitian sebelumnya telah dilaporkan bahwa ekstrak metanol daun mengkudu dapat membunuh larva nyamuk Aedes aegypti lebih banyak dibandingkan dengan pelarut n-heksan, kloroform, aseton dan air. Pada penelitian ini, senyawa pada fraksi n-heksan dari ekstrak etanol menunjukkan LC $_{50}$ sebesar 1040 ppm. ${ }^{28}$ Lemahnya aktivitas larvasida ini berkaitan dengan kemampuan fraksinasi dalam menarik senyawa aktif. Proses ekstraksi dipengaruhi oleh berbagai faktor diantaranya suhu, konsentrasi pelarut dan polaritas pelarut. Pelarut n-heksan akan banyak menarik senyawa yang bersifat non-polar karena memiliki indeks polaritas yang kecil. Lemak dan lapisan lilin yang terdapat pada permukaan daun dapat terbawa oleh pelarut ini, sedangkan tidak semua senyawa bersifat larvasida dapat terlarut dalam pelarut nonpolar..$^{29,30}$

Mekanisme aksi larvasida fraksi n-heksana masih belum diketahui secara jelas, karena bukti ilmiah terkait uji larvasida menggunakan senyawa tunggal dari daun mengkudu masih sedikit. Beberapa penelitian menjelaskan bahwa aksi larvasida, golongan senyawa terpenoid bekerja dengan menembus membran sel larva nyamuk yang bersifat hidrofobik dan membentuk misel atau agregat yang terbentuk dari membran sel larva sehingga menyebabkan perpindahan zat atau cairan dari dan keluar sel menjadi terganggu. ${ }^{31}$ Senyawa antrakuinon yang terdapat pada mengkudu berperan sebagai stomach poisoning yang dapat mengakibatkan gangguan sistem pencernaan larva Aedes sp. sehingga larva gagal tumbuh dan akhirnya mati. ${ }^{32}$

Sistem pencernaan larva nyamuk terdapat enzim yang berperan penting pada saluran pencernaan yakni enzim proteolitik (protease) dan enzim karbonik anhidrase (carbonic anhydrase). Enzim protease dapat ditemukan pada fase telur hingga nyamuk 
dewasa yang bekerja dengan mendegradasi nutrisi/makanan. Pada fase larva instar II-IV dilaporkan menunjukkan kadar enzim protease yang tinggi, karena larva sangat bergantung pada enzim protease dalam mencerna makanan. Enzim karbonik anhidrase mengatur $\mathrm{pH}$ saluran pencernaan dengan mengonversi karbon dioksida $\left(\mathrm{CO}_{2}\right)$ menjadi ion bikarbonat $\left(\mathrm{CO}_{2}^{3-}\right)$, hal inilah yang berperan dalam proses alkalisasi sehingga kondisi $\mathrm{pH}$ pada saluran cerna berkisar antara 7-11. Gangguan $\mathrm{pH}$ akan mengakibatkan malfungsi enzim dan aktivitas usus. ${ }^{33,34}$ Senyawa golongan tanin dapat menurunkan kemampuan mencerna makanan dengan menurunkan aktivitas enzim pencernaan serta mengganggu aktivitas protein usus sehingga terjadi penghambatan pertumbuhan dan gangguan nutrisi. ${ }^{35}$ Perkembangan larva hingga nyamuk sangat bergantung pada hormon pertumbuhan. Setiap pergantian fase instar pada larva dipengaruhi oleh hormon juvenile hormone $(\mathrm{JH})$, sedangkan pergantian fase larva menjadi nyamuk berkaitan erat dengan hormon prothoracicotropic hormone (PTTH). Terganggunya hormon tersebut dapat mengganggu metamorfosis larva menjadi nyamuk. ${ }^{36}$ Juvenile hormone $(\mathrm{JH})$ dijadikan sebagai target larvasida karena memengaruhi regulasi hormon endokrin, perkembangan abnormal dan hingga kematian larva. Senyawa fitosteroid pada tanaman leunca (Solanum nigrum) dilaporkan memiliki aktivitas larvasida terhadap Culex sp. dan Annopheles sp. dengan LC $_{50} 5.64 \mathrm{mg} / \mathrm{L}$ dan $3.68 \mathrm{mg} / \mathrm{L}$. Senyawa fitosteroid bersifat non-polar diduga berperan dalam penetrasi yang kuat ke dalam sel. Senyawa tersebut memengaruhi hormon endokrin dan perkembangan larva yang menyebabkan kematian larva secara fatal. ${ }^{37}$ Adapun flavonoid berperan dalam menghambat kerja enzim asetilkolinesterase. Enzim tersebut menghidrolisis neurotransmitter asetilkolin menjadi inaktif. Penghambatan enzim asetilkolinesterase menyebabkan akumulasi neurotransmitter asetilkolin pada celah sinaptik antar sel saraf, kondisi ini menyebabkan overstimulasi saraf yang menyebabkan paralisis atau kelumpuhan fungsi sel saraf dan sel otot. Flavonoid bersifat polar sehingga dapat masuk ke dalam tubuh larva melalui sistem pernapasan, kemudian akan menimbulkan kerusakan pada saraf dan sistem pernapasan yang mengakibatkan larva tidak bisa bernapas dan akhirnya mati. Kerusakan sistem pernapasan larva mengakibatkan larva harus mensejajarkan posisinya dengan permukaan air untuk mempermudah mengambil oksigen. ${ }^{38}$ Penelitian yang dilakukan oleh Raghav et al. juga melaporkan kandungan senyawa flavonoid (karanjin, karanja chromonen dan pongamol) menunjukkan aktivitas larvasida dengan menghambat enzim asetilkolinesterase. ${ }^{39}$

\section{KESIMPULAN}

Fraksi n-heksan ekstrak etanol daun mengkudu menunjukkan aktivitas larvasida terhadap larva Aedes sp. dengan LC $_{50}$ sebesar 1040 ppm dan LC $_{99}$ sebesar 2439 ppm.

\section{UCAPAN TERIMA KASIH}

Penulis menyampaikan terima kasih kepada Lembaga Penelitian dan Pengabdian kepada Masyarakat (LPPM) Universitas Darussalam Gontor dan pihak-pihak yang telah mendukung terlaksananya penelitian ini.

\section{KONTRIBUSI PENULIS}

Pada artikel ini, Rizki Awaluddin, Nurul Marfu'ah, dan Binti Solihatin berperan sebagai kontributor utama, sedangkan Kurniawan dan Solikah Ana Estikomah sebagai contributor anggota. Kontribusi setiap penulis dapat dilihat pada rincian berikut:

$\begin{array}{ll}\text { Konsep; Analisis Data; Menulis - Membuat Draft } & : \text { RA, BS } \\ \text { Kurasi Data } & : \text { RA, BS, NM }\end{array}$


Investigasi

Metodologi

Supervisi

Visualisasi
BS

RA, BS, NM, K

RA, BS, NM, SAE, K

BS, NM

\section{DAFTAR RUJUKAN}

1. Powell JR. Perspective piece mosquito-borne human viral diseases: Why aedes aegypti? Am J Trop Med Hyg. 2018; 98: 1563-1565.

2. Leta S, Beyene TJ, De Clercq EM, Amenu K, Kraemer MUG, Revie CW. Global risk mapping for major diseases transmitted by Aedes aegypti and Aedes albopictus. Int J Infect Dis. 2018; 67: 25-35.

3. Anonymous. Data Kasus DBD per Bulan di Indonesia Tahun 2010, 2009 dan 2008. Depkes RI: Jakarta. 2010.

4. Suryani E. The Overview of Dengue Hemorrhagic Fever Cases in Blitar City from 2015 to 2017. J Berk Epidemiol. 2018; 6: 260-267.

5. Kementerian Kesehatan Republik Indonesia. Laporan Kasus DBD di Indonesia hingga Juli 2020. Kementerian Kesehatan RI: Jakarta. 2020.

6. Jones RT, Ant TH, Cameron MM, Logan JG. Novel control strategies for mosquitoborne diseases. Philos Trans R Soc B Biol Sci. 2021; 376: 20190802.

7. Kesetyaningsih TW, Andarini S, Sudarto, Pramoedyo H. Determination of environmental factors affecting dengue incidence in Sleman District, Yogyakarta, Indonesia. African J Infect Dis. 2018; 12: 13-25.

8. Hamid PH, Prastowo J, Ghiffari A, Taubert A, Hermosilla C. Aedes aegypti resistance development to commonly used insecticides in Jakarta, Indonesia. PLoS One. 2017; 12: 1-11.

9. Satoto TBT, Satrisno H, Lazuardi L, Diptyanusa A, Purwaningsih, Rumbiwati et al. Insecticide resistance in Aedes aegypti: An impact from human urbanization? PLoS One. 2019; 14: 1-13.

10. Senthil-Nathan S. A Review of Resistance Mechanisms of Synthetic Insecticides and Botanicals, Phytochemicals, and Essential Oils as Alternative Larvicidal Agents Against Mosquitoes. Front Physiol. 2020; 10: 1-21.

11. Newman DJ, Cragg GM. Natural Products as Sources of New Drugs over the Nearly Four Decades from 01/1981 to 09/2019. J Nat Prod. 2020; 83: 770-803.

12. Bangun A, Sarwono B. Khasiat \& Manfaat Mengkudu. Agro Media Pustaka: Jakarta.2009.

13. Khanavi M, Najafi B, Sadati SN, Abai MR, Vatandoost H. Chemical constitute and larvicidal activity of fractions of Ajuga chamaecistus tomentella plant against malaria vector Anopheles stephensi. J Arthropod Borne Dis. 2017; 11: 116-123.

14. Charisma SL, Susilawati Y, Muhtadi A, Sadino A. Separation of ethyl acetate fraction of mengkudu fruit (Morinda citrifolia L.) and its hypoglycemic activity by glucose tolerance method. Res J Chem Environ. 2019; 23: 4-9.

15. Prabakaran P, Sivasubramania C, Veeramani. R, Prabhu S. Review Study on Larvicidal and Mosquito Repellent Activity of Volatile Oils Isolated from Medicinal Plants. Int J Environ Agric Biotechnol. 2017; 2: 3132-3138.

16. WHO. Guidelines for Laboratory and Field Testing of Mosquito Larvicides. : Geneva.2005.

17. Wigati D, Anwar K, Sudarsono, Nugroho AE. Hypotensive Activity of Ethanolic Extracts of Morinda citrifolia L. Leaves and Fruit in Dexamethasone-Induced Hypertensive Rat. J Evidence-Based Complement Altern Med. 2017; 22: 107-113.

18. Fajriaty I, Ih H, Setyaningrum R. Uji Kromatografi Lapis Tipis Dari Ekstrak Etanol Daun Bintangur (Calophyllum soulattri Burm . F). 2018; 7: 54-67. 
19. Theodora CT, Gunawan IWG, Swantara IMD. Isolasi Dan Identifikasi Golongan Flavonoid Pada Ekstrak Etil Asetat Daun Gedi (Abelmoschus manihot L.). J Kim. 2019; : 131.

20. Yuda PESK, Cahyaningsih E, Winariyanthi NLPY. Skrining Fitokimia dan Analisis Kromatografi Lapis Tipis Ekstrak Tanaman Patikan Kebo (Euphorbia hirta L.). Medicamento. 2017; 3: 61-70.

21. Bogitsh BJ, Carter CE, Oeltmann TN. Antropods as Vector. Fourth Edi. Academic Press: Tokyo.2013.pp:349-379.

22. Henriques BS, Garcia ES, Azambuja P, Genta FA. Determination of Chitin Content in Insects: An Alternate Method Based on Calcofluor Staining. Front Physiol. 2020; 11: $1-10$.

23. Ferede G, Tiruneh M, Abate E, Kassa WJ, Wondimeneh Y, Damtie D et al. Distribution and larval breeding habitats of Aedes mosquito species in residential areas of northwest Ethiopia. Epidemiol Health. 2018; 40: e2018015.

24. Kauffman E, Payne A, Franke M, Schmid M, Harris E, Kramer L. Rearing of Culex spp. and Aedes spp. Mosquitoes. Bio-Protocol. 2017; 7. doi:10.21769/bioprotoc.2542.

25. Farnesi LC, Brito JM, Linss JG, Pelajo-Machado M, Valle D, Rezende GL. Physiological and morphological aspects of Aedes aegypti developing larvae: Effects of the chitin synthesis inhibitor novaluron. PLoS One. 2012; 7. doi:10.1371/ journal.pone.0030363.

26. Sasmita HI, Tu WC, Bong LJ, Neoh KB. Effects of larval diets and temperature regimes on life history traits, energy reserves and temperature tolerance of male Aedes aegypti (Diptera: Culicidae): optimizing rearing techniques for the sterile insect programmes. Parasites and Vectors. 2019; 12: 1-16.

27. Anonim. Farmakope Herbal Indonesia. Kedua. Kementrian Kesehatan Republik Indonesia: Jakarta.2017.

28. Kovendan K, Murugan K, Shanthakumar SP, Vincent S, Hwang JS. Larvicidal activity of Morinda citrifolia L. (Noni) (Family: Rubiaceae) leaf extract against Anopheles stephensi, Culex quinquefasciatus, and Aedes aegypti. Parasitol Res. 2012; 111: 1481-1490.

29. Zhang QW, Lin LG, Ye WC. Techniques for extraction and isolation of natural products: A comprehensive review. Chinese Med (United Kingdom). 2018; 13: $1-26$.

30. Nawaz H, Shad MA, Rehman N, Andaleeb H, Ullah N. Effect of solvent polarity on extraction yield and antioxidant properties of phytochemicals from bean (Phaseolus vulgaris) seeds. Brazilian J Pharm Sci. 2020; 56. doi:10.1590/s217597902019000417129.

31. Yulianti L, Supriadin A, Rosahdi TD. Efek Larvasida Hasil Fraksinasi Ekstrak N-Heksana Daun Kirinyuh (Chromolaena odorata L.) Terhadap Larva Aedes aegypti. al-Kimiya. 2019; 4: 38-44.

32. Sere L, Arismianti N. Pengaruh Ekstrak Daun Mengkudu (Morinda citrifolia) Terhadap Kematian Larva Aedes sp. Univ Muhammadiyah Semarang. 2018; : 6-24.

33. Linser PJ, Smith KE, Seron TJ, Oviedo MN. Carbonic anhydrases and anion transport in mosquito midgut pH regulation. J Exp Biol. 2009; 212: 1662.

34. Saboia-Vahia L, Borges-Veloso A, Mesquita-Rodrigues C, Cuervo P, Dias-Lopes G, Britto $C$ et al. Trypsin-like serine peptidase profiles in the egg, larval, and pupal stages of Aedes albopictus. Parasites and Vectors. 2013; 6: 1-11.

35. Elumalai D, Hemavathi M, Hemalatha P, Deepaa CV, Kaleena PK. Larvicidal activity of catechin isolated from Leucas aspera against Aedes aegypti, Anopheles stephensi, and Culex quinquefasciatus (Diptera: Culicidae). Parasitol Res. 2016; 115: 1203-1212.

36. Zhang Q, Denlinger D. Molecular structure and expression analysis of the 
prothoracicotropic hormone gene in the northern house mosquito, Culex pipiens, in association with diapause and blood feeding feeding. Insect Mol Biol. 2012; 20: 201-213.

37. Rawani A, Ray AS, Ghosh A, Sakar M, Chandra G. Larvicidal activity of phytosteroid compounds from leaf extract of Solanum nigrum against Culex vishnui group and Anopheles subpictus. BMC Res Notes. 2017; 10: 1-8.

38. Fernandes DA, Souza MSR, Teles YCF, Oliveira LHG, Lima JB, Conceição AS et al. New sulphated flavonoids and larvicidal activity of helicteres velutina K. Schum (sterculiaceae). Molecules. 2018; 23: 1-11.

39. Raghav D, Mahanty S, Rathinasamy K. Biochemical and toxicological investigation of karanjin, a bio-pesticide isolated from Pongamia seed oil. Pestic Biochem Physiol. 2019; 157: 108-121. 